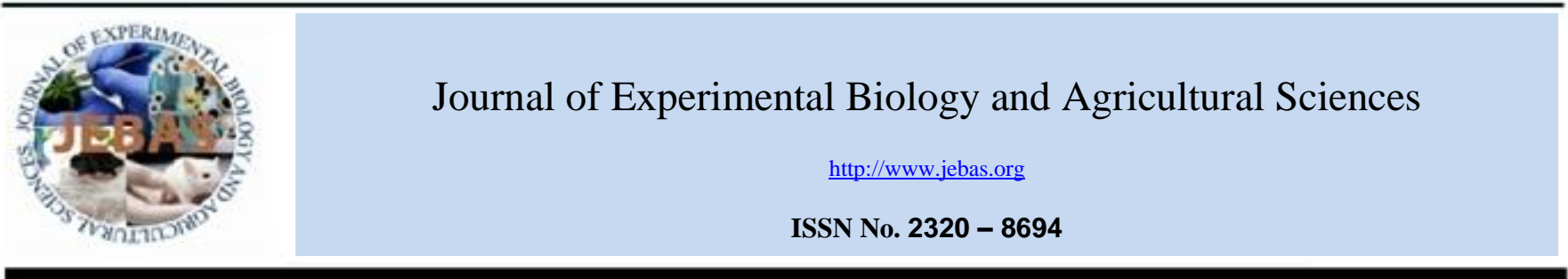

\title{
WATER AND FOOD SECURITY IN THE ARABIAN PENINSULA: STRUGGLING FOR MORE ACTIONS
}

\author{
A. Ouled Belgacem*, A. Nejatian, M. Ben Salah, A. Moustafa \\ International Center for Agricultural Research in the Dry Areas (ICARDA)-Arabian Peninsula Regional Program, Dubai UAE
}

Received - April 30, 2017; Revision - July 20, 2017; Accepted - July 26, 2017

Available Online - August 31, 2017

DOI: http://dx.doi.org/10.18006/2017.5(Spl-1-SAFSAW).S50.S62

KEYWORDS
Agriculture
Food
Security
ACARDian Peninsula
ICARD

\begin{abstract}
Food security is a critical issue for the Arabian Peninsula countries due fast population growth, reduced domestic food production and the tighter global food markets because of trading partners' strained export surpluses. Water scarcity is a major concern for the AP. The renewable water resources per capita is considered the lowest in the world and has decreased from $1250 \mathrm{~m}^{3}$ in 1950 to $76.2 \mathrm{~m}^{3}$ in 2014 . Furthermore, the projected water demand in AP for the year 2025 will exceed the double of the current groundwater availability, estimated at $8030 \mathrm{M} \mathrm{m}^{3}$.

In response to the alarming water situation, ICARDA in collaboration with the National Agricultural and Extension Systems (NARES) has established a program in AP, which has developed, evaluated, and introduced technology packages that empower growers to produce high-quality crops with less water. These technologies include: 1) the integrated forage production system based on indigenous plant species; 2) the introduction of spineless cactus as animal feed; and 3) protected agriculture with associated developed technologies such as soilless culture (hydroponics). Similarly, ICARDA and NARS works on date palm has resulted in improving water and land productivity for date production. Such water saving technology packages are being transferred to farmers in AP region through ICARDA and National scientists and extension agents.

Conclusively, a noticeable impact on the on-farm water management through the increased productivity per unit of water and land created. The demand for more applied research in the region is inevitable to ensure an adequate level of food security based on Climate-smart agriculture practice.
\end{abstract}

* Corresponding author

E-mail: a.belgacem@cgiar.org (Dr Azaiez Ouled Belgacem)

Peer review under responsibility of Journal of Experimental Biology and Agricultural Sciences.

Production and Hosting by Horizon Publisher India [HPI] (http://www.horizonpublisherindia.in/).

All rights reserved.
All the article published by Journal of Experimental Biology and Agricultural Sciences is licensed under a Creative Commons Attribution-NonCommercial 4.0 International License Based on a work at www.jebas.org.

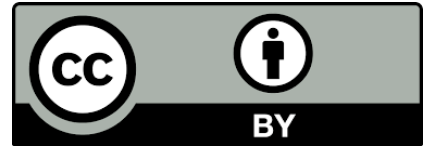




\section{INTRODUCTION}

The Arabian Peninsula (AP) countries include Bahrain, Kuwait, Oman, Qatar, Saudi Arabia, Yemen and the United Arab Emirates. Petroleum, accounts for $80 \%$ to $90 \%$ of merchandise export earnings which dominate the economy of the GCC member countries (Bazza, 2005). The region is potentially vulnerable to natural degradation process, hence threatening the sustainability of natural resources. This vast plateau is bounded by mountainous terrain and has been classified into 22 distinct agro-climatic zones (De Pauw, 2002). It covers a large landmass of about three million $\mathrm{km}^{2}$ (Batanoumy, 1986; ICARDA, 2007) and Saudi Arabia occupies by far the greater part. It is characterized as an ecologically fragile region which constitutes one of the largest contiguous arid zones in the world (De Pauw, 2002).

The AP is already passing the water scarcity threshold as outlined by the World Health Organization (WHO). The shortage of renewable water resources and the growing inconsistency between demand and supply of water is a major challenge. Rapidly growing demands, which is a result of a rapid population growth, further worsen water scarcity. Other factors which affecting water scarcity includes unsustainable consumption, climate change, and weak management institutions and regulations. On top of all, lack of efficient technology to increase water use efficiency specialty in agriculture is a major issue (Odhiambo, 2016).

The UN Water report considered the Arabian Peninsula one of the most vulnerable areas to climate change impacts (UN Water, 2012). It is expected that temperature rise in the region up to $2 \mathrm{C}$ in the next 15-20 years, and over $4 \mathrm{C}$ for the end of the century (IPCC 2007). These climate projections means hotter, drier and less predictable climate, for the region.

Reviewing the food security indicators for the seven, AP countries reveal that with the exception of Yemen, all AP countries are in an acceptable range of the food security in terms of availability, access and utilization. However, the food price indicators and their dependency on food import present an unstable situation regarding the food security over the time in the region. For the AP countries with their high food-import dependency and limited agricultural potential, trade and budget balance play important roles in food security. The high GDP, which generated from oil export enable them to import food items from international market. However, these countries will be vulnerable to any international and regional constrains and conflict which affect the world food market. On top of that, any matter, which affects the oil revenue and trade balance, would affect the food security too. Yemen doesn't have access to the hard currency generated from oil export compared to the GCC countries and the food insecurity indicators, already exacerbated by the political instability and civil war; exhibit an urgent need for a food security program.

With this context, the national macro food security can be considered as an indicator for the country food insecurity and calculated according to the following formula (Breisinger et al., 2012):

$$
\begin{aligned}
& \text { Macro Food Security }= \\
& \frac{\text { Total Food Imports }(\% \text { of GDP) }}{\left(\begin{array}{c}
\text { Total exports of good and services }(\% \text { of GDP) } \\
+
\end{array}\right)} \\
& \text { Net remittances }(\% \text { of GDP) }
\end{aligned}
$$

The macro food security can be enhanced by adding some other indicators such as percentage of malnutrition children even if this figure is very low or data is not available if Yemen is not considered. Table 1 presents the status of the macro food insecurity indictor in the AP.

Table 1 show that the AP countries can be classified in two groups. The first includes the six GCC countries which face a low risk of food insecurity, while these countries will be vulnerable to any international and regional constrains and conflict, which affect the world food market. Nevertheless, reducing oil price also affecting the trade balance of these countries. The second group includes only Yemen which is facing a very high risk of food insecurity already aggravated by the civil war which has affected government and multilateral capacity to provide food-safety net programmes and has undermined food safety.

Table 1 Food insecurity indicators and AP countries ranking base on 2011 data

\begin{tabular}{|lc|rrr|}
\hline & $\begin{array}{c}\text { Food } \\
\text { import } \\
\text { (\% of } \\
\text { GDP) }\end{array}$ & $\begin{array}{c}\text { Total exports } \\
\text { of goods and } \\
\text { services } \\
\text { (\% of GDP) }\end{array}$ & $\begin{array}{c}\text { Remittances } \\
\text { (Net inflows }\end{array}$ & $\begin{array}{c}\text { Macro } \\
\text { Food }\end{array}$ \\
\hline Bahrain & 2.5 & 96.5 & -8.6 & $\begin{array}{c}\text { Security } \\
\text { indicator }\end{array}$ \\
\hline Kuwait & 1.4 & 65.1 & -6.2 & 2.9 \\
\hline Oman & 3.1 & 57.6 & -8.2 & 6.2 \\
\hline Qatar & 1.2 & 57.5 & & 2.0 \\
\hline Saudi Arabia & 2.4 & 65.3 & -4.4 & 4.0 \\
\hline UAE & 3.1 & 89.3 & & 3.4 \\
\hline Yemen & 7.5 & 38.0 & 11.0 & 15.4 \\
\hline
\end{tabular}

To reduce the risk of food insecurity in all AP countries, developing an agricultural and food production systems based on water use efficient and high yield techniques is very important. Their fragile natural resources should be used in a smart way to produce strategic food resources to downgrade the international market threat.

\section{Challenges to Agricultural Development}

In the Arabian Peninsula, the human insecurity regarding sustainable livelihoods and food security is largely being determined by the limited arable fields which are estimated to be less than 3\% of the total land area (Dabbour, 2006). Moreover, 
agriculture is faced with enormous natural challenges which are directly linked to the productivity and sustainability of the local agricultural production systems.

\subsection{Climatic Extremes}

Most of the Arabian Peninsula like the United Arab Emirates (UAE) is classified as hyper-arid with aridity index $<0.03$ (UNCCD, 2004). Spatial and temporal distribution of rainfall is an additional complicating factor. The driest country is Oman with $62 \mathrm{~mm} /$ year on average, followed by the other countries of the Arabian Peninsula (FAO, 2010). Rainfall is low and irregular, with a severe water deficit throughout the year. With few exceptions, mean annual rainfall is between $30 \mathrm{~mm}$ to $150 \mathrm{~mm}$ hence is recognized as one of the driest subcontinents in the world (De Pauw, 2002). Temperatures are high rather very high and exceed $50^{\circ} \mathrm{C}$ in the summer when relative humidity is also high (ICARDA, 2007). More than $90 \%$ of the area has a mean annual temperature of $20^{\circ} \mathrm{C}$. Potential evapotranspiration is very elevated in the interior of the Peninsula and decreases towards its edges, and huge negative balance between water supply by precipitation and evaporative demand of the atmosphere exists (De Pauw, 2002).The hyper-arid conditions in the Arabian Peninsula may expand in the area under the climate change scenario of overall global warming.

\subsection{Scarce Water Resources}

Water scarcity in this arid region limits the agricultural development particularly and reduces the scope for its diversification. But inappropriate policies and technological solutions have placed emphasis on meeting self-sufficiency in food production leading to rapid growth of the agricultural sector in recent decades. As a consequence of this phenomenon, water requirements have increased beyond naturally sustainable levels (Mahdi, 2001), and depletion of groundwater aquifers is now common to most parts of this region (Odhiambo, 2016).

The primary sources of freshwater are groundwater, most of which is non-renewable, and a limited amount of renewable surface water. The absence of administrative and legal regulations to control pumping encouraged unlawful drilling and resulted in inefficient irrigation practices (Al-Zubari, 1997). The subsidies increased the irrigated areas as well as agricultural production but resulted in the mining of fossil aquifers.

The Arabian Peninsula countries are the most water-scarce countries in the world. The renewable water resources per capita decreased from $1250 \mathrm{~m}^{3}$ in 1950 to $100 \mathrm{~m}^{3}$ in 2007 (WRI, 2007) and $76.2 \mathrm{~m}^{3}$ in 2014 (World Bank, 2017) while considered the lowest in the world.Kuwait has no internal renewable water resources. Average annual internal renewable water resources (IRWR) per inhabitant in 2014 ranged from $0 \mathrm{~m}^{3}$ in Kuwait to 311 $\mathrm{m}^{3}$ in Oman (FAO, 2017). The distribution of total actual renewable water resources (TARWR) followed asimilarpattern in
2014, with values ranging from $5.1 \mathrm{~m}^{3}$ per inhabitant in Kuwait and $331 \mathrm{~m}^{3}$ in Oman (FAO, 2017).Water demand in all these countries is steadily increasing due to expansion in all sectors particularly agricultural activities and public needs by increasing population. Total water demand in all countries rose from 6.6 to $22.5 \mathrm{~B} \mathrm{~m}$ during the period of 1980-1990 and is expected to reach 36.7 billion $\mathrm{m}^{3}$ by 2025 (Jardat, 2005). Since agriculture depends on irrigation and uses 80 to $90 \%$ of the water resources, the agricultural water demand is estimated to be $24.3 \mathrm{~B} \mathrm{~m}$ per year (Uitto \& Schneider, 1997). Water requirements for 2010 calculated at 28.2 billion $\mathrm{m}^{3}$ as against the projected groundwater availability of 18030 million $\mathrm{m}^{3}$ in the Peninsula.

Multi-layered aquifer systems, centered in the Arabian Peninsula mainly in Saudi Arabia, extend over an area of around 1.5 million $\mathrm{km}^{2}$ (FAO, 2010). Fossil groundwater, a non-renewable resource located in deeper sedimentary aquifers, serves as the dependable source of water. The reserves of this groundwater in the Arabian Peninsula are estimated to be $2175 \mathrm{~B} \mathrm{~m}^{3}$ (Jardat, 2005). The main source for irrigation in the Arabian Peninsula countries is groundwater where the withdrawal reached 17611 million $\mathrm{m}^{3}$ while total recharge was only 6360 million $\mathrm{m}^{3}$ in 1997 resulting in $63 \%$ annual recharge deficit (Abdulrazzak, 1997). Saudi Arabia is the country with the highest withdrawals in the Arabian Peninsula at 9 percent of the total withdrawals in the Middle East (FAO, 2010). The majority of this storage is brackish with a range of 200-20,000ppm total solids dissolved in it. As withdrawal is increasing day by day, the salinity levels of these deep aquifers fresh water are gradually becoming higher (Bazza, 2005). Several aquifers in Bahrain, Oman, Qatar, and UAE are already severely affected by this phenomenon.

For handling the imbalances in water demand and supply, several non-conventional sources, including brackish water, desalinated seawater and wastewater have been explored and added as essential components of the annual water balance. Since the 1950s and early 1960s, the region has gained significant experience in desalination and produces more than $40 \%$ of the total desalinated water in the world (Bazza, 2005). As reported by FAO in 2010, the Arabian Peninsula countries are the most advanced regarding non-conventional sources of water: desalinated water represents 8 percent and reused treated wastewater 2 percent of the total water withdrawal. Saudi Arabia and the United Arab Emirates account for $32 \%$ and $29 \%$ respectively of the use of desalinated water in the Middle East region. In absolute terms, three countries (Saudi Arabia, the United Arab Emirates and Kuwait) are by far the largest users of desalinated water, accounting for 77 percent of the region's total. Saudi Arabia uses an annual $1033 \mathrm{M} \mathrm{m}^{3}$ and the United Arab Emirates and Kuwait 950 and $420 \mathrm{M} \mathrm{m}^{3}$ respectively (FAO, 2010). Qatar and Kuwait rely primarily on desalination for domestic water supplies because of the depletion of fresh groundwater; UAE and Bahrain follow them. Eventually, the desalinated and treated waste water contribute about 7.2 percent and 1.7 percent, respectively to the total annual available water 
(Al Zubari, 1997).The collection and treatment of municipal wastewater have reached about $60 \%$ in the GCC countries. In Yemen, this figure is not very clear but based on data presented by Ministry of Electricity \& Water in 2000, the total number of the treatment stations in Yemen were 9 stations with the total actual flow of the treated wastewater around $92,000 \mathrm{~m}^{3}$ per day. In most countries, treated water is used for the irrigation of landscaping after treatment to the tertiary level. It is inevitable that these countries will depend mainly on the utilization of this type of water, although its proper use is still controversial

Actually, the sustainability indicator of renewable water resources shows a gleaming future for all Arabian Peninsula countries unless courageous policy measures are taken and implemented urgently.

With this context, FAO-AQUASTAT alarmed as follow: "concerning freshwater withdrawal to the renewable water resources in the Middle East region, the Arabian Peninsula stands out with values over 100 percent in all the countries, except Oman, indicating that more water is withdrawn than the quantity annually renewed on a long-term basis, thus depleting the fresh water resources and using fossil groundwater. At the country level, Kuwait has by far the highest water indicator, 2075 percent, meaning that considerable use is made of fossil groundwater. The United Arab Emirates and Saudi Arabia follow, with 1867 percent and 936 percent respectively. In contrast, freshwater withdrawal in Oman represents 91 percent of renewable water resources."

\subsection{Population proliferation}

The countries of the Arabian Peninsula have relatively small human populations, which nevertheless grew rapidly between the 1950 and 2007 and are projected to continue to increase over the next 50 years (Fahimi \& Kent, 2007). In 2008, the region for ecast population for 2015 was estimated as 44.7 million heads @ 2.7\% annual growth and projected as 78.08 million in 2030 and 103.0 million by 2050 at an average growth rate of $1.9 \%$ (FAO, 2008). However, the reported population for the seven AP countries during 2017 has reached a peak of 82.9 Million (Worldometers, 2017), which is higher than the previously expected number of people for 2030 and clearly indicates the higher population growth rate than anticipated in 2008. About $73 \%$ of the AP population lives in Saudi Arabia and Yemen.

\subsection{Research Infrastructure and Human Resources}

The biggest challenge facing agricultural development in the Arabian Peninsula is lack of eminence research infrastructure, as centers of excellence with qualified and professional staff. At the moment, the National Agricultural Research Systems (NARS) are facing sever lack of human development programs specifically to develop qualified researchers in order to conduct high quality research and share the research outputs with the National Agricultural Extension Services (NAES).

\section{Agriculture and Food Security in the Arabian Peninsula}

Food security in the Arabian Peninsula has a long history of environmental and socio-economic pressures and vulnerabilities associated with the complicated active relationship between agriculture and the dry climate system (Tolba \& Saab, 2009).Increasing quantities of food imports would be required to feed the fast growing populations. The estimated food production in the Arabian Peninsula during 2010 was 17,754 thousand tons compared to demand of 41,811 thousand tons with a deficit of 24,057 thousand tons. High dependence on food imports in the region means that regional countries would be exposed to greater risks notably Yemen, which imported $90 \%$ of wheat and wheat flour as a staple food (FAO, 2004).

Food security is fast becoming a critical issue for countries in the Arabian Peninsula because of deficit domestic food production, and population growth as $60 \%$ of food is already being imported in the Gulf. Hence, wealthier countries of the Arabian Peninsula, fearing that some day they might not be able to secure enough food for their populations, have increased government subsidies, built up strategic storage, and invested in agriculture overseas (Woertz et al., 2010).

Most of the Arabian Peninsula is unsuited to settled agriculture which is less than $1 \%$ of the land area. Out of a total cultivable area of 59 million ha, only 2.7 million ha are cultivated, or 5 percent of the potential. The cultivated area per person economically active in agriculture varies from a low $0.2 \mathrm{ha} /$ person in Oman to $0.4 \mathrm{ha} /$ person in Yemen and Qatar (FAO, 2010). The main reason for this small percentage is a lack of enough water for irrigation. Although cropped areas are very limited in the peninsula but are mostly irrigated utilizing $>85 \%$ of fresh water resources (Taha et al, 2004; Jardat, 2005; Tolba \& Saab, 2009). Although agriculture consumes most of the available water, it contributes far less than $1 \%$ of Gross Domestic Product. Annual growth rate of agriculture was $2.6 \%$ during 1990-2005 and it was not expected to go above $2.5 \%$ till 2030 (FAO, 2008).

Over the past 20-30 years, the Arabian Peninsula countries, with policy measures, aimed at achieving a greater level of food selfsufficiency. The plan focused on economic incentives for expanding the area under irrigation and improving crop productivity. Governments provided subsidies in several forms, including wells, fuel, energy, inputs, price support programs, trade protection, and free access to unlimited amounts of groundwater most of which is non-renewable. It increased steadily in Oman and very rapidly in the UAE, but declined in Saudi Arabia reflecting the abandoning of some areas where groundwater resources had been exhausted. Severe drop in agricultural productivity in the UAE occurred between 2000 and 2004 and 
was attributed to the depletion of groundwater resources and the consequent change in agricultural policy.

Implementation of the policy to increase the level of selfsufficiency achieved its objectives to a certain extent, but at an extremely high economic cost and the loss of huge amounts of traditional reserves of fossil water resources. Yet, the countries continued to have low food sufficiency rates for the main food commodities, except fruits and vegetables to a certain extent. From the economic standpoint, the subsidies distorted costs and revenues and many of the agricultural activities were financially profitable only because of government grants and incentives.

Pressurized irrigation techniques are common in the Arabian Peninsula where sprinkler and localized irrigation are practiced on over half of the area. Surface irrigation is also being practiced. As a matter of fact, in all countries, except Saudi Arabia and the United Arab Emirates, it is prevailing on more than three-quarters of the area, and in Yemen, it is probably the only irrigation method in use (FAO, 2010). Thus, water demand in agriculture opens avenues for producing more with less water. This potential for improvement resides in the poor performance of irrigated agriculture in the Arabian Peninsula regarding productivity per unit of water and land, even under modern irrigation techniques. In future, agriculture is expected to use less water to produce more to supply growing demand for food and at the same time to release some of the water it is now consuming. There is a need for the more efficient use of water in agriculture by incorporating water saving crops, more efficient irrigation practices, improving water control at farm levels and by eliminating irrigation on marginally productive lands. Future investment in research for development program would probably be the best approach to address this situation by developing appropriate technology packages for the Arabian Peninsula.

\section{ICARDA in the Arabian Peninsula}

Since its establishment in 1977, ICARDA has actively collaborated with the AP countries through technical backstopping about its mandated crops and areas of research, exchange of germplasm, and human resource development through training and visits of scientists. In 1988, ICARDA began a special program for the AP countries which included the following projects.

- $\quad$ Strengthening Barley and Wheat Research and Training in the Arabian Peninsula(1988-1995)

- Strengthening Agricultural Research and Human Resource Development in the Arabian Peninsula (1995-2000)

- Sustainable Management of Natural Resources and Improvement of Major Production Systems of the Arabian Peninsula (2000-2005)
- Development of Sustainable Date Palm Production Systems in the GCC Countries of the Arabian Peninsula (2004-2009)

- Technology Transfer to Enhance Rural Livelihoods and Natural Resource Management in the Arabian Peninsula (2007-2013)

- Improving food security and sustainable natural resources management through enhancing integrated agricultural production systems in the Arabian Peninsula (2014-2018)

The last project (2014-2018) was designed to build on the results of the previous research projects on water use efficiency, irrigated forage, rangeland rehabilitation, and protected agriculture.

In response to the dangerous water situation, ICARDA's research for development program focused on the challenges of agricultural production and natural resources management in the Arabian Peninsula. The program in collaboration with the National Agricultural and Extension Systems (NARES), has developed, evaluated, and introduced technology packages that empower growers to produce high-quality crops with less water.

\subsection{Collection of valuable germplasm in Arabian Peninsula and identification of potential indigenous species for the production of forages}

The Peninsula, no doubt has substantial potential as a source of genetic diversity and abiotic stress resistance where the climate is the primary determinant of potential biomass productivity of plants and crops(De Pauw, 2002). In line with this undeniable fact, during 1998 to 2004, nine plant collection missions for major indigenous forage grasses, legumes, shrubs, and trees were conducted with the active participation of NARES partners in all Arabian Peninsula countries. Total 190 plant species were collected and identified. A list of highly promising species was compiled according to observations and discussions with farmers, herders and scientists as per potential use of local plants for rangeland rehabilitation and as forage crops. Some forages and fodder crops were screened and their performance under moderate to high salinity and water stress conditions (Figure1) were studied. Their palatability and nutritive value were also assessed in comparisons with both exotic forages (Alfalfa and Rhodes grass).

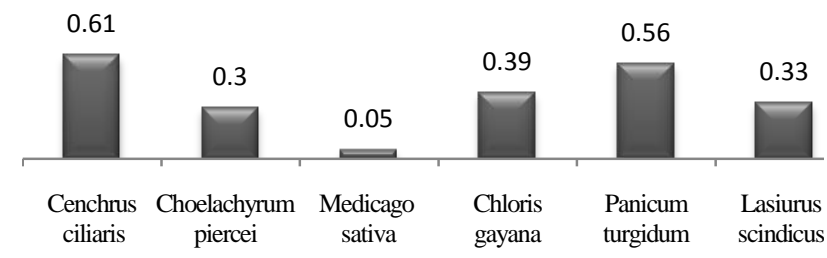

Figure 1 Dry matter production of six forages ( $t /$ ha) under deficit irrigation

The indigenous grasses (Cenchrus ciliaris, Coela chyrumpierci, and Lasirius scindicus) were very much drought tolerant and 
capable of producing under extremely limited irrigation $(23,500$ $\mathrm{m}^{3} /$ ha/year).

Data on the chemical composition showed that the indigenous species were comparable to the exotics (Table 2). Buffel grass was almost similar to Rhodes grass in crude protein $(9.6 \%$ and $9.4 \%$, respectively), in-vitro dry matter digestibility and in neutral detergent fiber NDF) contents.

Table 2 Chemical composition of indigenous grasses and the exotic Rhodes grass

\begin{tabular}{|ccccc|}
\hline & $\begin{array}{c}\text { Cenchrus } \\
\text { ciliaris }\end{array}$ & $\begin{array}{c}\text { Coelachyrum } \\
\text { piercei }\end{array}$ & $\begin{array}{c}\text { Lasiurus } \\
\text { scindicus }\end{array}$ & $\begin{array}{c}\text { Chloris } \\
\text { gayana }\end{array}$ \\
\hline $\begin{array}{c}\text { Crude } \\
\text { protein } \\
(\%)\end{array}$ & 9.6 & 7.8 & 6.9 & 9.4 \\
\hline $\begin{array}{c}\text { Neutral } \\
\text { detergent } \\
\text { fiber (\%) }\end{array}$ & 70.1 & 71.9 & 79.1 & 72.9 \\
\hline $\begin{array}{c}\text { Acid } \\
\text { detergent } \\
\text { fiber (\%) }\end{array}$ & 38.6 & 40.1 & 49.3 & 38.8 \\
\hline $\begin{array}{c}\text { Acid } \\
\text { detergent } \\
\text { insoluble } \\
\text { N (\%) }\end{array}$ & 0.1 & 0.1 & 0.1 & 0.1 \\
\hline $\begin{array}{c}\text { Ash (\%) } \\
\text { Sources: Peare }\end{array}$ & 10.0 & 8.8 & 7.2 & 9.6 \\
\hline
\end{tabular}

Sources: Peacock et al., 2003

Overall, $C$. ciliaris has been identified as the forage that offers high-quality feed and high water-use efficiency (Dakheel et al., 2000). It can be harvested ten times a year, with an average dry matter yield of up to $20 \mathrm{t} / \mathrm{ha}$.

One of the main bottle neck for expansion of indigenous grass species as irrigated forages in the region was the lack of seeds. APRP achieved significant improvements on the range and forages' seedmultiplication methods in Arabian Peninsula. Seed propagation fields for native grass established chronically in UAE, Oman, Yemen, and Qatar, while shrub seeds were produced in large quantities in Saudi Arabia.

Seed production technology in the Arabian Peninsula is not fully established therefore most of the seeds used in the region is imported. However, recognizing its significance finally, seed production of promising selected native forage species has been started with a determination to obtain sufficient quantities for its subsequent mechanized seed multiplication. Seed Technology Units were established in UAE, Oman, Qatar, Yemen and Saudi Arabia; where bulk seed samples of important grasses are being collected and threshed with help from Seed Technology Units. The units maximized seed yields, using precision thresher machinery, and removing impurities of seeds by air screen cleaners and help to determine optimum harvest time. More than 40 plant species were targeted for producing bulk quantities of seed under both drip and central pivot irrigation systems.

\subsection{Introduction of Cactus (Opuntia spp.) as alternative forage crop and for rangeland rehabilitation}

For pastureimprovement and as alternative feed, the ICARDAAPRP has introduced 38 accessions of spineless cactus to establish a focal nursery in Oman in 2005. Four auxiliaries of Oman nursery have been created inUAE, Qatar, Saudi Arabia and Yemen.

The introduction of spineless cactus to the Arabian Peninsula region was based on the success achieved by ICARDA in North Africa region where thousands of hectares are in production of cactus pads for animal feed and fruits for human consumption.

Spineless cactus (Opuntia spp.) is well recognized for its ability to survive severe drought and the harsh environmental conditions. As an animal feed, cactus is a good source of water, Vitamin A and $\mathrm{Ca}$ and is best utilized by animals in combination with saltbush. In sandy and deep soils, it may successfully establish with mean annual rainfall of $100-150 \mathrm{~mm}$. The characteristics of cacti plant offer most of the requirements of a drought-resistant forage crop. As a matter of fact, they possess a specific photosynthetic mechanism, which leads to a more efficient production of dry matter per unit water consumed than that of grasses or legumes. Even though the introduced accessions presented high variability and different performances in relation to vegetative and reproductive growth parameters, all the studies carried out in the different countries show that spineless cactus can easily grow and produce under the harsh environmental conditions of the Arabian Peninsula region. Most of the studied spineless cactus accessions and cultivars showed good performances to generate important fodder for livestock, and numerous varieties produced an important quantity fruits for human consumption (OuledBelgacem et al., 2017). In Al Jouf region, Saudi Arabia, the optimum water requirement of Spineless Cactus proved to be $2500 \mathrm{~m}^{3} / \mathrm{ha} /$ year of which $1550 \mathrm{~m}^{3} / \mathrm{ha}$ are needed during the hot period (March-September) and $750 \mathrm{~m}^{3} / \mathrm{ha}$ during the relatively cold period (October-February).

In Qatar, a comparison study was conducted for selection of cactus accessions which have thepotential for both fruit production and animal feed. The study showed that the average number of new pads per year exceeded 37 while the number of fruits was more than 10 per year per plant. Among38 accessions, 10 seem to be more suitable for producing both cladodes for animal feed and fruits for human consumption. 
4.3 Conserving environment and producing high nutritious cash crops with minimum amount of agrochemicals by application of IPPM techniques

The extensive use of chemicals to control diseases and pests in greenhouses results in complex problems of insect resistance, and health and environmental hazards. Crops can be protected by control measures that avoid heavy reliance on pesticides, thereby reducing the use of hazardous chemicals. These controls are part of an Integrated Production and Protection Management (IPPM) program developed and implemented in all AP research stations andprivate pilot farms with very promising results (Figure 2). Application of IPPM increased water use efficiency about 50\% and cut down the 18-22 pesticide sprays to 2-3 sprays per seasons (Al Kirshi et al., 2003).

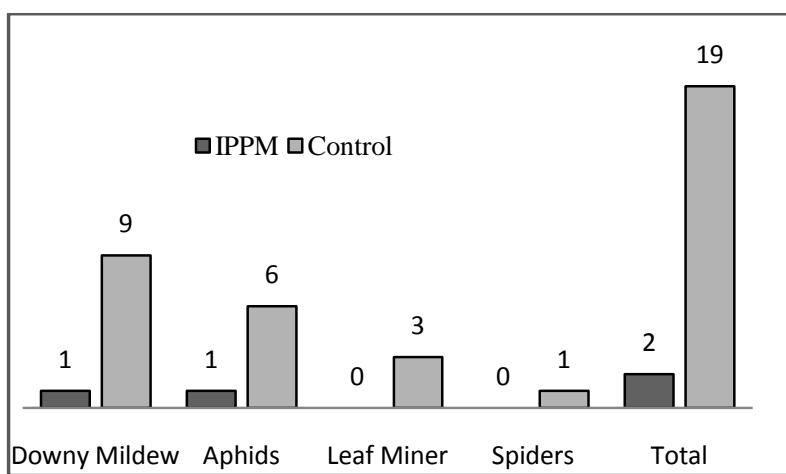

Figure 2 Number of Spray under GH for IPPM and Control units in Yemen (2013)

As a part of the IPPM program, soil solarization techniques were developed and simplified for growers and a special booklet published. The method was implemented on research stations and private farms with excellent results, avoiding the use of hazardous chemicals.

\subsection{Increasing water use efficiency with soil-less culture in greenhouses}

The quantity and quality of water required to produce high-value crops are practically impossible to obtain in a dry region such as the AP. The underground water level has rapidly declined, and the water has increasing salt content. Expensive desalination is necessary for good quality fresh water.

Soil-less techniques can improve water use efficiency, plant protection, and water and fertilizer management in crop production. The primary objectives were to increase yield quality and quantity per unit of water, area, and workforce. The soil-less growing techniques are becoming popular and are being adopted in AP countries.

Since 1998, ICARDA has conducted several collaborative adaptive research and agro-economic studies with NARS scientists in AP countries, with promising results. Yields were increased significantly and productivity per unit water increased by $>70 \%$ compared to soil-based systems. Thus growers could increase their production area without requiring more water.

For instance, in Kingdom of Saudi Arabia (KSA), one on farm study was conducted at six farms. Two greenhouses in each farm were selected. The soilless production systems installed in one of the greenhouses while the other ones were left under the farmer's management as control units. Tomato crop was planted in all greenhouses. The average water productivity reached about 40 $\mathrm{kg} / \mathrm{m}^{3}$ with the soilless system while in soil it was only $9 \mathrm{~kg} / \mathrm{m}^{3}$ for the same farmers. Therefore, it can be stated that with the same amount of water, the soilless production systems could produce 4.5 times more than conventional soil based systems in KSA.

In another study in Yemen on cucumber with soilless (open system) during summer 2013, the results showed that the soilless system increased water use efficiency by $71 \%$. Water productivity of cucumber under soilless system reaches to 76 $\mathrm{kg} / \mathrm{m}^{3}$ versus $22 \mathrm{~kg} / \mathrm{m}^{3}$. Cost benefit analysis also shows that net income in soilless system is higher than conventional soil system by two times. Research activities for further enhance and more simplifying the techniques are continued by ICARDA in collaboration with NARES.

4.5 Alternative feed resources: valuing the poor agroindustrial by-products

In Arabian Peninsula (AP), there is scope to replace areas under fodder crops with cereals for human consumption by using, innovating and developing alternative animal feed resources. Pellets and feed blocks mix agricultural and agro-industrial byproducts and silage with a feed ration. Feed block technology is simple and does not require sophisticated equipment. Blocks are easy to handle, transport, and can be made on the farm. ICARDA and NARS in AP Countries are studying formulae for feed blocks with different amounts of urea, binders, and agro-industrial byproducts available locally, mainly from the date palm. The project established feed block units in Oman, Qatar, UAE and Yemen for study and demonstration (ICARDA, 2016).

The alternative feed resources such as feed block can contribute to water conservation in the dry areas through:

- Considering the amount of water consumed by the crops during the growth stages, using the crop and plants residue after the harvest for animal feed would increase the efficiency of irrigation water;

- Utilizing alternative animal feed would reduce the pressure on scared water resources for the production of irrigated forages. 
- The other crops such as spineless cactus, which are being used for feed block, use less water compared to the most of irrigated forage species.

\subsection{Enhancing date palm production}

\subsubsection{Boosting pollination}

ICARDA and NARS examined the effect of extraction and drying methods on the viability of pollen grains, fruit characteristics, and productivity. Good pollination can enhance date production as the viability of pollen affects germination rates. Studies aimed to find the best extraction and drying methods, and the storage conditions conducive to viable pollen sustainability and high germination percentages.

As a result of these studies, ICARDA introduced the Liquid pollination techniques which increase productivity and profits for date palm growers. In the date palm, only female trees bear fruit and female flowers must first be pollinated by male trees. Traditional pollination methods are slow, costly, and require trained labor. Liquid pollination - where female trees are sprayed with pollen solution, using a hosepipe it is much quicker, cheaper, and equally effective.

\subsubsection{Testing bio-pesticides}

The loss of the date palm production by pest attacks is valued to about 30-40\% reduction in profit (El-Juhany, 2010). Old World Date Dust Mite (Oligonychus afrasiaticus McGregor) and the Lesser Date Moth (Batrachedra amydraula Meyrick) are considered the dominant acarian pests of date palm in the GCC region and causes severe yield loss, particularly in young developing date fruit.

Biological control including the use of biological pesticides, gives good results against the two pests. The organic-pesticide Coragen $0.15 \mathrm{ml} / \mathrm{L}$ gave the best results in comparison with the other insecticides on Lesser Date Moth in Oman (Al-Khatri et al., 2017). In KSA, related to Al-Bather et al. (2016) three bio pesticides (Matrin 0.5\%, Paraffin oil, Abamectin1.8\%) against Date Dust Mite.

\subsubsection{Speeding up drying}

Drying dates aim to preserve the quality of the fruit and reduce losses. The results of trials of solar drying in glasshouses were very promising, shortening the drying period and improving the quality of the dried fruit. The time required for drying and ripening dates was cut by half, from 8 to 4 days. The quality of dried dates improved because the glasshouses prevented damage by insects and birds, meaning that they fetched better prices at market (Chouili et al., 2016).

\subsubsection{Producing quality planting offshoots}

The UAE and ICARDA are investigation the effect of date palm fertigation and applying Mycorrhizae on young date palms at $\mathrm{Al}$ Hamrania research station. Insemination of plants by Mycorrhizae aims to: (1) improve vegetative growth, (2) increase productivity, and (3) reduce water consumption by more than half (Al Sayari et al., 2016).

\subsection{Success Stories in Technology Development and Transfer}

\subsubsection{Introducing Buffel grass to growers in UAE}

In 2016 and with drip irrigation system, Buffel grass take the exotic forages places on a large number of farms in the UAE. Similarly, in other six countries of the Peninsula, its cultivations at pilot farms are scaling up.

While mitigating the upscaling needs for quality seed, seed multiplication fields, as well as Seed Technology Units, have been established in Emirates, Oman, Qatar, Yemen and Saudi Arabia. This Buffel technology package is an output of a decade-long collaborative research for development program of APRP with a parallel focus on capacity building and institutional strengthening of National Agricultural Research Services. Buffel is rapidly spreading all around and as a matter of fact, its demand is growing rapidly day by day because farmers themselves are the best promoters of a right technology to other fellows.

NARS support has asignificant impact on up-scaling this technology package. The Oman government and Abu Dhabi Farmers' Services Center in UAE are supporting and educating growers to replace Rhodes grass the widely used forage species with the more beneficial and less water consuming Buffelgrass. Nearly 10,500 farms in the Emirate of Abu Dhabi have stopped the cultivation of Rhodes grass as announced by ADFCA in May 2012 (Gulf News, 2012).

\subsubsection{Increasing farmer incomes in Yemen mountain terraces through protected agriculture and IPPM}

To elevate poor farmer incomes in the mountain terraces of Yemen, the cultivation of cash crops in simple greenhouses was introduced. Using a participatory approach, some greenhouses were established in farmers' fields in different locations. Drip irrigation was novel and of interest to farmers under terrace conditions, due to water scarcity. The intensive production system allowed poor farmers to produce high-quality vegetable crops with less water. Their income significantly increased, as well as production per unit of water and area. Cost-benefit analysis indicated that the total cost of greenhouses could be recovered within three seasons (Figures $3 \& 4$ ). 


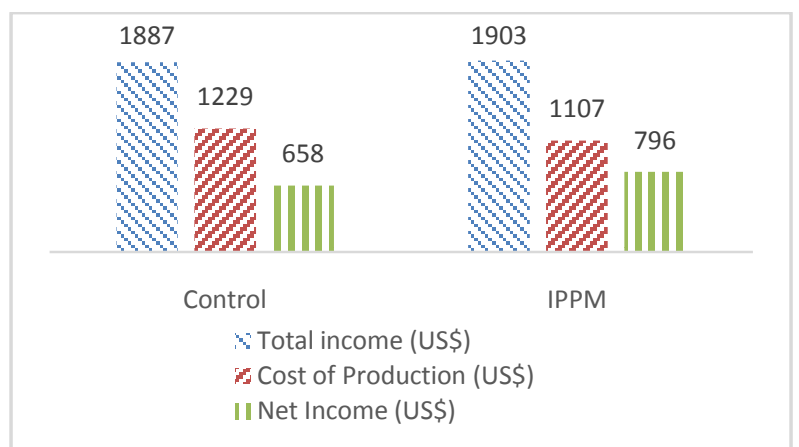

Figure 3 Comparison of income, cost of production and net income of cucumber crop in IPPM and control system in Yemen during 20152016 growing season (greenhouse size $408 \mathrm{~m}^{2}$ )

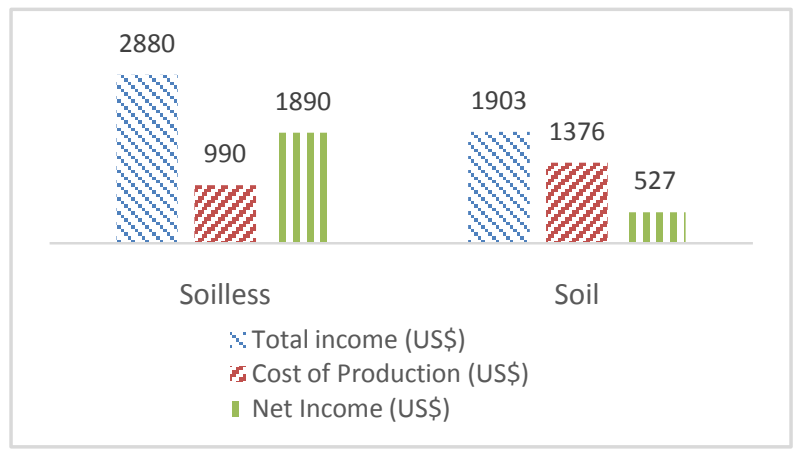

Figure 4 Comparison of income, cost of production and net income of cucumber crop in soil and soilless system in Yemen during 2015-2016 growing season (greenhouse size $408 \mathrm{~m}^{2}$ )

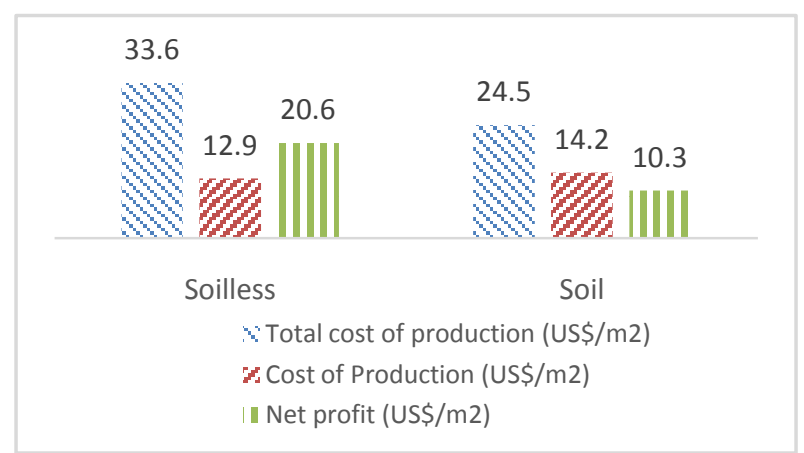

Figure 5 Financial indicators of soil and soilless (Hydroponics) production systems for cucumber with cooled greenhouse (US\$/ $\left.\mathrm{m}^{2}\right)$

Socio-economic studies showed that farmers significantly increased the water use efficiency and also increased their income up to $400 \%$ by producing high-quality cash crops in a single span greenhouse of $270 \mathrm{~m}^{2}$ (Solh \& Moustafa, 2009). In 2016, a partial budget study was conducted in Yemen. The following graphs show the IPPM and soilless technology package net benefits compared to conventional production in soil under greenhouse conditions Yemen.

\subsubsection{Soil-less production techniques for high-quality crops} with less water

Simplified Hydroponics techniques were successfully transferred to the growers in all seven countries. By the end of 2016, a significantnumber of producers adopted this production method. Only in UAE as reported by the NARS officials, the number of GHs equipped with soilless production techniques passed 1000 greenhouses in 2014. The hydroponics systems have led to them assive saving of water and higher profit for the farmers. In some cases, water saving in hydroponics increased more than $90 \%$ compared to conventional soil base systems.

ICARDA studies revealed that utilizing soilless culture can result in reducing fertilizers use by up to $20 \%$ compared to soil bed systems. The cost of production, yield and net profit for cucumber in hydroponics and soil-based system under protected agriculture are presented in Figure 5. These data calculated for three cropping seasons. Data collected from pilot growers in UAE (Nejatian et al., 2016). The net income for cucumber is about double under soilless production system compared to conventional soil based systems.

With soilless culture under protected agriculture, crops can be produced year round regardless of season, so multiple cropping on the same unit of land is possible. The flexibility of the system means that farmers can take advantage of market seasonality and higher prices. Furthermore, the system could provide growers with the opportunity of production of high-value crops that cannot produce otherwise (Moustafa et al., 2003).

An agro-economic study comparing production and cost of strawberry in a vertical hydroponics system and conventional soil bed system in Kuwait revealed substantial increase in output in yield by 4.6 folds (Figure 6). The total cost of production in the vertical hydroponics system was $40 \%$ less than soil based cultivation (Figure 7), while the production per unit of water increased by $70 \%$ (Moustafa et al., 2006).

\section{Conclusion and recommendations}

Water scarcity is a major concern for the present and future inhabitants of the Arabian Peninsula (AP), which is causing serious threat to the region's food security. In this context, ICARDA's research for development program focused on the challenges of agricultural production and natural resources management in the AP. The program in collaboration with the National Agricultural and Extension Systems (NARES), has developed, evaluated, and introduced technology packages that empower growers to produce high-quality crops with less water.

The integrated forage production system based on indigenous plant species achieved $100 \%$ higher water productivity compared to traditionally grown exotic Rhodes grass. 


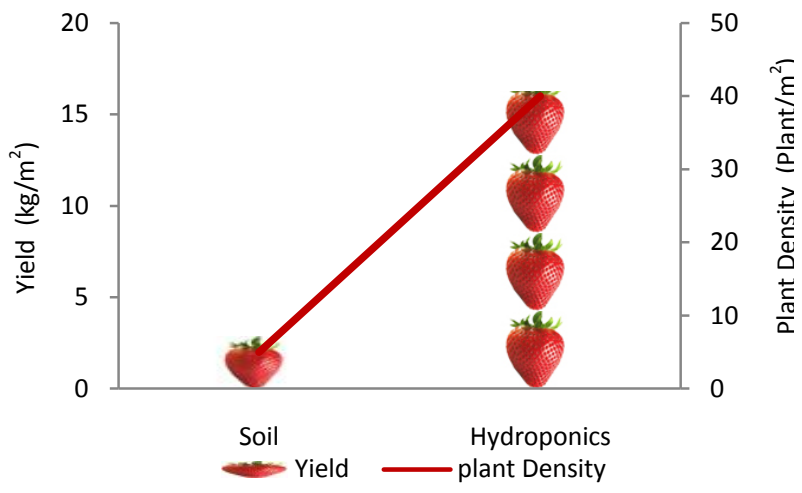

Figure 6 Comparison between the plant density and yield of strawberries produced from Soil beds and Hydroponics growing systems (Moustafa et al., 2006)

The introduction of spineless cactus as feed offered great scope to rehabilitate rangelands and marginal farmlands, particularly in Oman, Saudi Arabia and Yemen.

Protected agriculture with associated developed technologies such as the integrated production \& protection management (IPPM) and soilless culture (hydroponics) offers valuable and economical options to producing high-quality fruit and vegetable crops with less water.

ICARDA and NARS works on date palm has resulted in improving water and land productivity for date production.

Such water saving technology packages are being transferred to farmers through ICARDA and NARES scientists and extension agents in all AP countries where the outcomes of such research for development activities created a noticeable impact on the onfarm water management through the increased productivity per unit of water and land.

However, for further expansion and up scaling, the demand for more applied research in the region is inevitable to ensure an adequate level of food security. More investment in research for development activities and infrastructure are needed to sustain the natural resources base. This could be seen as the establishment of an advanced research center for desert development to address sustainable agriculture production system, renewable energy, conventional and non-conventional water resources, etc. The importance of research activities for agricultural development and food security should be cleared and highlighted for the decision makers.

On the other hand, Although the state of the art technology is required and should be utilized for answering the region challenges facing agricultural development and food security, domestic resources and knowledge are equality important and must be taken into consideration in developing appropriate technology packages suitable for the local conditions.

Human resources development also is a bottleneck for agricultural development in the region. Even though the number of researchers with postgraduate degrees in some of the countries such as Oman increased significantly in the recent years, still there is an urgent need for improving quantity and quality of human resources in both agricultural research and extension systems.

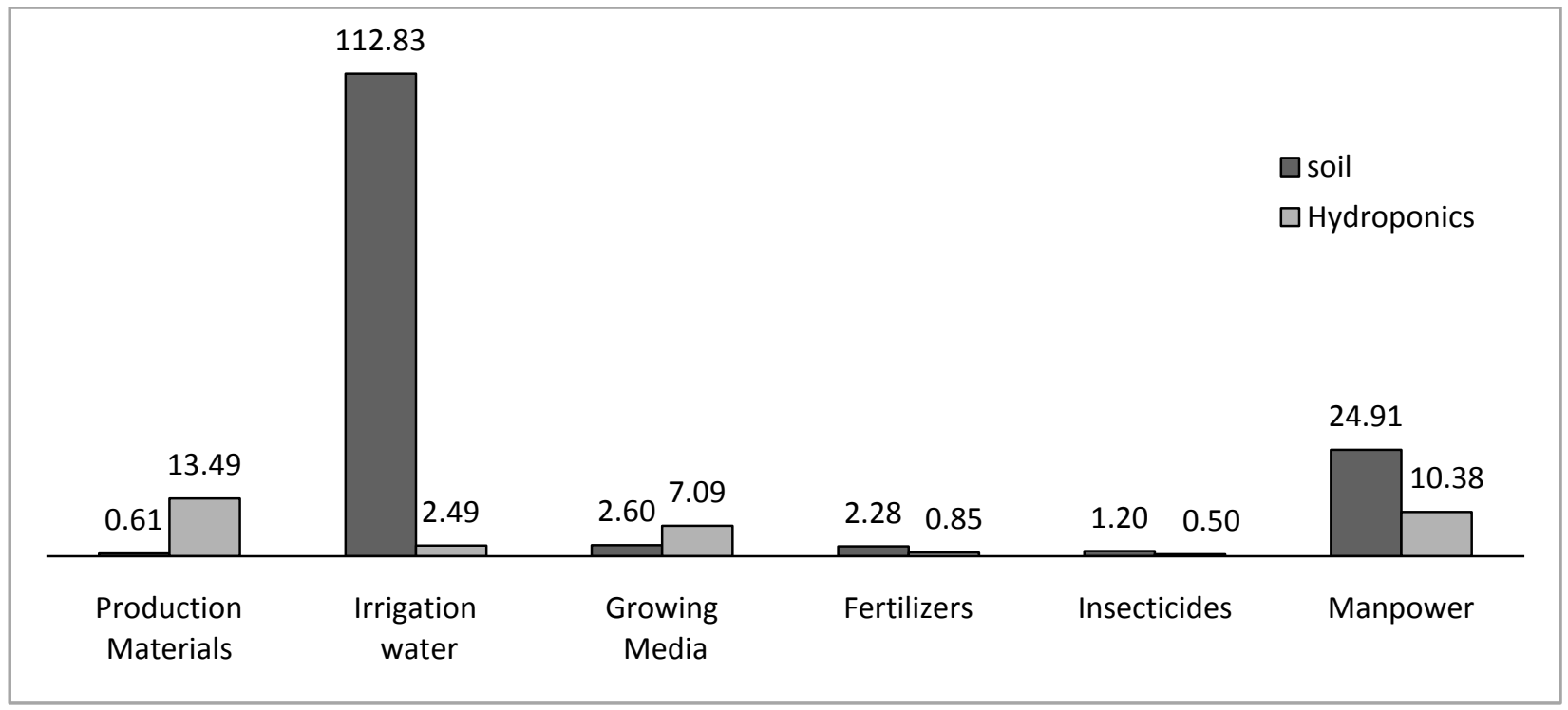

Figure 7 Cost of different production items ('000 US\$) to grow 100,000 strawberry plants in Vertical Hydroponics and conventional soil bed system in Kuwait (Moustafa et al., 2006). 
Stronger collaborations with the regional and international institution are highly important. There is a popular quote from an unknown source that says "If you want to be incrementally better: Be competitive. But if you want to be exponentially better: Be cooperative." Overcome the climate change impacts and move toward the food security, require the new technology to be applied to the crop varieties, pests, food preferences, and agricultural practices of each region which are an enormous task that requires leading-edge science, global cooperation, and resources of the global agricultural research and development agencies. Furthermore, a regional network would provide a suitable platform for sharing the research results among the national and international research institutions.

\section{Acknowledgements}

The authors would like to acknowledge the dedication, hard work and support of the management, researchers and scientists of the national research and extension systems of Arabian Peninsula countries.

ICARDA is deeply grateful to the donors of the Arabian Peninsula Regional Program- the Arab Fund for Economic and Social Development (AFESD), the International Fund for Agricultural Development (IFAD) and the OPEC Fund for International Development (OFID) - for their interest, encouragement and the highly valued financial support. Their care and consideration were a major force behind the success of this program.

Conflict of Interest: The authors declare that they have no conflict of interests.

\section{References}

Abdulrazzak M (1997) The future of freshwater resources in the Arabian Peninsula. In: Uitto JI, Schneider J(1997)The fresh water resources in arid lands. The United Nations University, 53-70, Tokyo 150, Japan.

Al-Bather SM, Al-Shagag A, Al-Saroj S, Al-Bagshi M, Abdullah I, Al-Shawwaf A, Ben Salah M (2016) Effectiveness of Some Bio-pesticides against the Dust Mite Oligonychus afrasiaticus in Date Palm. International Conference on the Investment in Date Palm sector (reality and prospects) held on 23-25 May, 2016 at Muscat-Oman.

Al Kirshi A, Al Ragihi N, Al Thoris A (2003) Dissemination of Integrated Production and Protection Management Techniques of

Cucumber Pests in Protected Agriculture under Farmers' Condition in Dhamar, Yemen. ICARDA-APRP Annual Report 2002-03 page 175-177. Dubai, UAE.

Al Sayari A, Mazahrih N, Ben Salah M, Salah AM (2016) The effect of mycorrhiza and organic fertilizers on the growth of four
Date palm seedlings under nursery conditions. MAE- UAEICARDA. Unpublished report.

Al-Khatri S, Al-Abri N, Al-Aufi M, Al-Busaidi A, Al-Hamadani R, Al-Yahmadi A, Al-Khumaisi M, Al-Ahsani M, Ben Salah M (2017) Efficiency of some insecticides against Lesser Date Moth, Batrachedra amydraula. The 1st International Conference on "Integrated Protection of Date Palms. March 13, 14, 2017. Al Manama, Kingdom of Bahrain. Arabian Gulf University-The National initiative on Agricultural Development.

Al-Zubari WK (1997) Towards the establishment of total cycle management and re-use program in the GCC countries. Presented at the $7^{\text {th }}$ Regional Meeting of the Arab International Hydrological Programme Committee, 8-12 September, Rabat - Morocco.

Bazza M (2005) Policies for Water Management and Food Security under Water-scarcity Conditions: The Case of GCC Countries. $7^{\text {th }}$ Gulf Water Conference held on 19-23 November, 2005 at Water Science and Technology Association, Kuwait, FAO.

Batanoumy KH (1986) Rangelands of the Arabian Peninsula with a special reference to the history of range management the Hemaan old Arabian Reserve System, Proceeding of the $2^{\text {nd }}$ Int'l Rangeland Congress, Adelaide, Australia, Pp 234-235.

Breisinger C, Ecker O, Al-Riffai P, Yu B (2012) Beyond the Arab Awakening, policies and investments for poverty reduction and food security. Washington, DC: IFPRI.

Chouili KM, Sedrani M, El Amria A, Ghafria B, Sayabi H, Khanjari Y, Raissi Y, Ben Salah M (2016) Drying dates in Polycarbonate Houses in Oman. International Conference on the Investment in Date Palm sector (reality and prospects) held on 2325 May, 2016 at Muscat-Oman.

Dabbour N (2006) Water resources and their use in agriculture in Arab countries. Journal of Economic Cooperation 27 :1-38.

Dakheel A, Ferguson ME, Al-Hadrami G, Saleh A, McCann IR, Peacock JM (2000) Desert forages of the Arabian Peninsula-the sustainable use of salt affected soils through conservation and evaluation. Int'l seminar-'Prospects for saline agriculture' held on April 10-12, 2000 at Islamabad, Pakistan.

De Pauw E (2002) An agroecological exploration of the Arabian Peninsula, ICARDA, Aleppo, Syria, Pp. 77.

El-Juhany LI (2010) Degradation of Date Palm Trees and Date Production in Arab Countries: Causes and Potential Rehabilitation. Australian Journal of Basic and Applied Sciences 4: 3998-4010.

Fahimi FR, Kent MM (2007) Challenges and opportunities-The population of the Middle East and North Africa. Population 
Bulletin, Population Reference Bureau (PRB), Vol. 62, No. 2, USA.

FAO (2004) Proceeding of Follow up to the World Food Summit and World Food Summit: five years later: Regional Dimensions. Twenty-seventh FAO regional conference for the Near East held on March 13-17, 2004 at Doha, Qatar.

FAO (2008) Near East agriculture towards 2050: Prospects and challenges, Proc. Twenty-ninth FAO Regional Conference for the Near East. March 1-5, Cairo, Egypt.

FAO (2010) General summary Middle East region- Arabian Peninsula. AQUASTAT, FAOs' Information System on Water and Agriculture. Available on http://www.fao.org/nr/water/aquastat/regions/meast/index.stm Accessed on February, 2010.

FAO (2017) AQUASTAT Data. Retrieved from AQUASTAT: http://www.fao.org/nr/water/aquastat/data/query/index.html?lang= en, Accessed on February, 2010.

Gulf News (2012) Farms stop cultivating Rhodes grass. Retrieved from http://gulfnews.com/news/uae/environment/farms-stopcultivating-rhodes-grass-1.998624, Accessed on February, 2010.

ICARDA (2007) ICARDA in the Arabian Peninsula- Ties that bind, Twenty years of collaboration in scientific agricultural research for development between the National Agricultural Research Systems of the Arabian Peninsula countries and ICARDA, International Centre for Agricultural Research in Dry Areas (ICARDA), Aleppo, Syria, Vi+52pg.

ICARDA (2016) ICARDA-APRP Progress report. Dubai, UAE. 30 pages + annexes

IPCC (2007) Climate change 2007: impacts, adaptation and vulnerability. In: Parry ML, Canziani OF, Palutik JP, van der Linden PJ, Hanson CE (Eds) Contribution of working group II to the fourth assessment report of the intergovernmental panel on climate change. Cambridge University Press, Cambridge.

Jaradat AA (2005) Saline agriculture in the Arabian Peninsula: Management of marginal lands and saline water resources. Journal of Food, Agriculture, and the Environment 3:302-306.

Mahdi KA (2001) Water in the Arabian Peninsula: problems and policies. Available on www.encyclopedia.com/doc/1P3305776481.html Accessed on February, 2010.

Moustafa AT, Al Bakry A, Al Rawahi M, Al-Mohammadi AR, Ahmed R (2003) Development of Soilless Growing Techniques for the Production of High Quality Cash Crops using Less Water in the Arabian Peninsula, More Crops per Drop. Proceeding of 7th
International Conference on Dryland Development (IDDC) 14-17 Sep 2003, Tehran, Iran, pp. 485-488.

Moustafa AT, Oraifan S, Al Bakri A, Nejatian A (2006) High Density Cropping System for Cash Crop Production in Marginal Land with Less Water. Proceeding of $8^{\text {th }}$ IDDC Beijing, china, Aleppo, Syria, Pp. 839-842.

Nejatian A, Ganan A, OuledBelgacem A (2016) Factors affecting the adoption of soilless production system in UAE. International Journal of Agriculture Extension 04 : 119-131.

Odhiambo OG (2016) Water scarcity in the Arabian Peninsula and socio-economic implications. Applied Water Science 7 : 1-14.

OuledBelgacem A, Nejatian A, Al Farsi S, Al Wawi HM, AlSharari M, Al-Hamoodi A, Louhaichi M (2017) Spineless cactus in the Arabian Peninsula: adaptive behaviors and production performances. IX International Congress on Cactus Pear and Cochineal "CAMs crops for a hotter and drier world". March: $26^{\text {th }}$ $-30^{\text {th }}$. Coquimbo, Chile.

Peacock JM, Ferguson ME, Alhadrami GA, McCann IR, Al-Hajoj A, Saleh A, Karnik R (2003) Conservation through utilization: a case study of the indigenous forage grasses of the Arabian Peninsula. Journal of Arid Environment 54: 15-28.

Solh ME, Moustafa A (2009) Improving livlihood of small farmers through the production of high value horticultural crops in protected agriculture in dry areas. International Conference on Horticulture, Bangalore, India

Taha KF, Ismail S, Jaradat A (2004) Prospects of Saline Agriculture in the Arabian Peninsula. The Association for Environmental Health and Sciences, Pp. 576.

Tolba MK, Saab NW (2009) Arab Environment: Climate ChangeImpact of Climate Change on Arab Countries. Arab Forum for Environment and Development, Beirut 150 pages.

Uitto JI, Schneider J (997) The fresh water resources in arid lands. The United Nations University, 53-70, Jingumae 5-chome, Shibuya-ku, Tokyo 150, Japan

UNCCD (2004) Combating desertification. A glossary. Bonn: UNCCD. Available on http//www.unccd.intknowledge/glossary.php access on February, 2017.

UN Water (2012) Global Annual Assessment of Sanitation and drinking-water (GlAAS) 2012 report: the challenge of extending and sustaining services. UN, New York

Woertz E, Lippman T, Wilcox O, Boucek C (2010) Food Security in the Arabian Peninsula. Thursday, January 14, Washington, 
D.C

Available

http://www.carnegieendowment.org/events/?fa=eventDetail\&id=2 798 access on February, 2017.

World Bank (2017) Renewable internal freshwater resources per capita (cubic meters). Retrieved from The World Bank: available on

http://data. worldbank.org/indicator/ER.H2O.INTR.PC?end=2014

\&start=1962, access on February, 2017.

World Bank (2012) 2012 World Development Indicators.
Washington, DC: World Bank.

Worldometers (2017) Countries in the world by population (2017). Retrieved from World ometers: available onhttp://www.worldometers.info/world-population/population-bycountry/ access on February, 2017.

WRI (2007) Actual Renewable Water Resources: Per capita. Retrieved 2010, from Earth Trends: available on http://earthtrends.wri.org/text/water-resources/variable-694.html access on February, 2017. 